\title{
Reduced Genetic Variation in Populations of Black Cherry (Prunus serotina subsp. serotina, Rosaceae) at Its Western Range Limit in Kansas
}

\author{
Author(s): James B. Beck, Carolyn J. Ferguson, Mark H. Mayfield and Joey
}

Shaw

Source: Northeastern Naturalist, 21(3):472-478.

Published By: Eagle Hill Institute

DOI: http://dx.doi.org/10.1656/045.021.0313

URL: http://www.bioone.org/doi/full/10.1656/045.021.0313

BioOne (www.bioone.org) is a nonprofit, online aggregation of core research in the biological, ecological, and environmental sciences. BioOne provides a sustainable online platform for over 170 journals and books published by nonprofit societies, associations, museums, institutions, and presses.

Your use of this PDF, the BioOne Web site, and all posted and associated content indicates your acceptance of BioOne's Terms of Use, available at www.bioone.org/page/ terms of use.

Usage of BioOne content is strictly limited to personal, educational, and non-commercial use. Commercial inquiries or rights and permissions requests should be directed to the individual publisher as copyright holder. 


\title{
Reduced Genetic Variation in Populations of Black Cherry (Prunus serotina subsp. serotina, Rosaceae) at Its Western Range Limit in Kansas
}

\author{
James B. Beck ${ }^{1, *}$, Carolyn J. Ferguson ${ }^{2}$, Mark H. Mayfield ${ }^{2}$, and Joey Shaw ${ }^{3}$
}

\begin{abstract}
We compared genetic variation at five nuclear simple sequence repeat loci between three populations of Black Cherry (Prunus serotina subsp. serotina) at the edge of its western range in Kansas to four populations from within the range interior. Although within-population expected heterozygosity did not differ between edge and core populations, allelic richness was significantly lower in the edge populations. This finding is consistent with a loss of rare alleles due to genetic drift in demographically unstable edge populations.
\end{abstract}

\section{Introduction}

The non-random distribution of species is one of the most salient features of life on earth, and understanding the forces that shape species' ranges remains an area of intense interest in ecology and evolution (Antonovics 1976, Bridle and Vines 2007, Hoffmann and Blows 1994, Mayr 1963). Many models of range dynamics feature adaptation (or lack thereof) to local conditions at range edges (Sexton et al. 2009). Because adaptation requires genetic variation, these models include assumptions regarding the relative amount of genetic variation across species' ranges. The abundant center model (ACM) is commonly invoked. This model assumes that environmental conditions are most favorable at the range center, becoming increasingly less so towards range margins (Brown 1984, reviewed in Sagarin and Gaines 2002). This cline in habitat suitability creates increasingly lower effective population sizes and increased genetic differentiation among populations near range margins. Together, these features limit adaptive potential in edge populations due to an overall loss of variation through genetic drift and the swamping effects of maladaptive alleles arriving from relatively large interior populations (Bridle and Vines 2007, Kirkpatrick and Barton 1997, Vucetich and Waite 2003).

Although this prediction of reduced genetic variation toward range edges has been the subject of numerous studies (reviewed in Eckert et al. 2008), few of them have examined these dynamics in central North America - an area of major biotic change, a transition zone for various forest ecosystems of eastern North America to the Great Plains grasslands (Barbour and Christensen 1993, Küchler 1972). In particular, many eastern North American plant species reach their western range limits here (Kartesz 2013), presumably in response to decreasing precipitation.

\footnotetext{
${ }^{1}$ Department of Biological Sciences, Wichita State University, Wichita, KS 67260. ${ }^{2}$ Herbarium and Division of Biology, Kansas State University, Manhattan, KS 66506. ${ }^{3}$ Department of Biological and Environmental Sciences, University of Tennessee at Chattanooga, Chattanooga, TN 37403. ${ }^{*}$ Corresponding author - james.beck@wichita.edu.
}

Manuscript Editor: Donald J. Leopold 
A particularly dramatic example is Prunus serotina Ehrh. subsp. serotina (Black Cherry: Rosaceae). This taxon forms part of Prunus serotina s.1., which also includes P. serotina subsp. hirsuta (Ell.) McVaugh (Alabama Cherry) from the highlands of Alabama and Georgia; subsp. eximia (Small) McVaugh from the Edwards Plateau; subsp. virens (Woot. \& Standl.) McVaugh from west Texas, New Mexico, Arizona, and northern Mexico; and subsp. capuli (Cav.) McVaugh (Capulí) from southern Mexico and Guatemala (McVaugh 1951). Although McVaugh assigned some individuals from Mexico and Guatemala to subsp. serotina, the main range of P. serotina subsp. serotina is in eastern North America, where it is found essentially throughout the United States east of $96^{\circ}$ west longitude, at which point its range ends somewhat abruptly (Prasad and Iverson 2003). This longitudinal range boundary presents an opportunity to evaluate the ACM's prediction of reduced genetic variation in edge populations by comparing them to populations from well inside the main Black Cherry range.

\section{Methods}

\section{Field sampling}

Samples were obtained from seven $P$. serotina subsp. serotina populations in 2012. These included four populations from within the range interior and three populations at or near the western edge of its range in Kansas (Fig. 1). Names and geographic coordinates for each population are as follows: Chisholm Creek Park, KS $\left(37.7429^{\circ} \mathrm{N}, 97.2740^{\circ} \mathrm{W}\right)$; Cross Timbers State Park, KS $\left(37.8039^{\circ} \mathrm{N}\right.$, $\left.95.8446^{\circ} \mathrm{W}\right)$; Osage State Fishing Lake, KS $\left(38.7711^{\circ} \mathrm{N}, 95.6649^{\circ} \mathrm{W}\right)$; University of Wisconsin-Milwaukee Field Station, WI $\left(43.3906^{\circ} \mathrm{N}, 88.0260^{\circ} \mathrm{W}\right)$; Catoosa County, GA $\left(34.9250^{\circ} \mathrm{N}, 85.0620^{\circ} \mathrm{W}\right)$; Lewis County, TN $\left(35.5608^{\circ} \mathrm{N}\right.$, $\left.87.4440^{\circ} \mathrm{W}\right)$; and the Tyson Research Center, MO $\left(38.5250^{\circ} \mathrm{N}, 90.5577^{\circ} \mathrm{W}\right)$. The Chisholm Creek Park population is particularly extreme geographically. Of the 143 Kansas specimens of Black Cherry at the Kansas State University (KSC) and University of Kansas (KANU) herbaria, only two were collected farther west (just $0.23^{\circ}$ and $0.07^{\circ}$ westward). The Kansas populations were found in finite forested patches within agricultural or urban landscapes, and the interior populations were in areas of relatively continuous forest. Trees were informally sampled, although we made an effort to sample broadly across each local area. We obtained silica-dried leaf tissue from 10 individuals at the Catoosa County, GA site, and from each of 20 individuals in the remaining six populations. A voucher specimen from one individual per population was archived at the Kansas State University Herbarium (KSC), the University of Tennessee at Chattanooga Herbarium (UCHT), or the Wichita State University Herbarium (WICH).

\section{DNA extraction and SSR genotyping}

We extracted DNA from 130 samples using a modified CTAB protocol designed for 96-well plates (Beck et al. 2012), except that we performed tissue grinding using the reciprocating saw bead-mill described by Alexander et al. (2007). We assessed microsatellite, or simple sequence repeat (SSR), allele variation at five previously 
published loci (UDP96-005 and UDP98-405 [Cipriani et al. 1999], UCD-CH14 [Struss et al. 2003], PceGA34 [Downey and Iezzoni 2000], and M4c [Yamamoto et al. 2002]). Although P. serotina is a putative allotetraploid, three of these loci (UDP96-005, UDP98-405, and UCD-CH14) are specific to one of the two parental genomes (Pairon and Jacquemart 2008). Locus M4c is not specific to either parental genome (Pairon and Jacquemart 2008), and PceGA34 has not been evaluated. We labeled forward primers for each locus with 6-FAM or HEX, and the five loci were amplified using a multiplex PCR protocol (one triplex and one duplex). Each 8- $\mu \mathrm{L}$ reaction contained 2.5 $\mu 12 \mathrm{X}$ Qiagen Multiplex PCR Master mix (Qiagen, Germantown, MD), $0.2 \mu \mathrm{M}$ each primer, and $\sim 20 \mathrm{ng}$ DNA template. Reactions involved denaturing at $95{ }^{\circ} \mathrm{C}$ ( 15 minutes) and 30 cycles of $94{ }^{\circ} \mathrm{C}$ denaturing ( 30 seconds), annealing at $53{ }^{\circ} \mathrm{C}\left(90\right.$ seconds), and extension at $72{ }^{\circ} \mathrm{C}(60$ seconds $)$, followed by a final extension at $60^{\circ} \mathrm{C}$ (30 minutes). Amplicons were sized using the $500 \mathrm{LIZ}$ standard on an Applied Biosystems 3730xl DNA Analyzer (LifeTechnologies, Carsbad, CA) at the University of Chicago Comprehensive Cancer Center DNA Sequencing and Genotyping Facility (Chicago, IL). Alleles were determined using GeneMarker 1.9 (SoftGenetics, State College, PA).

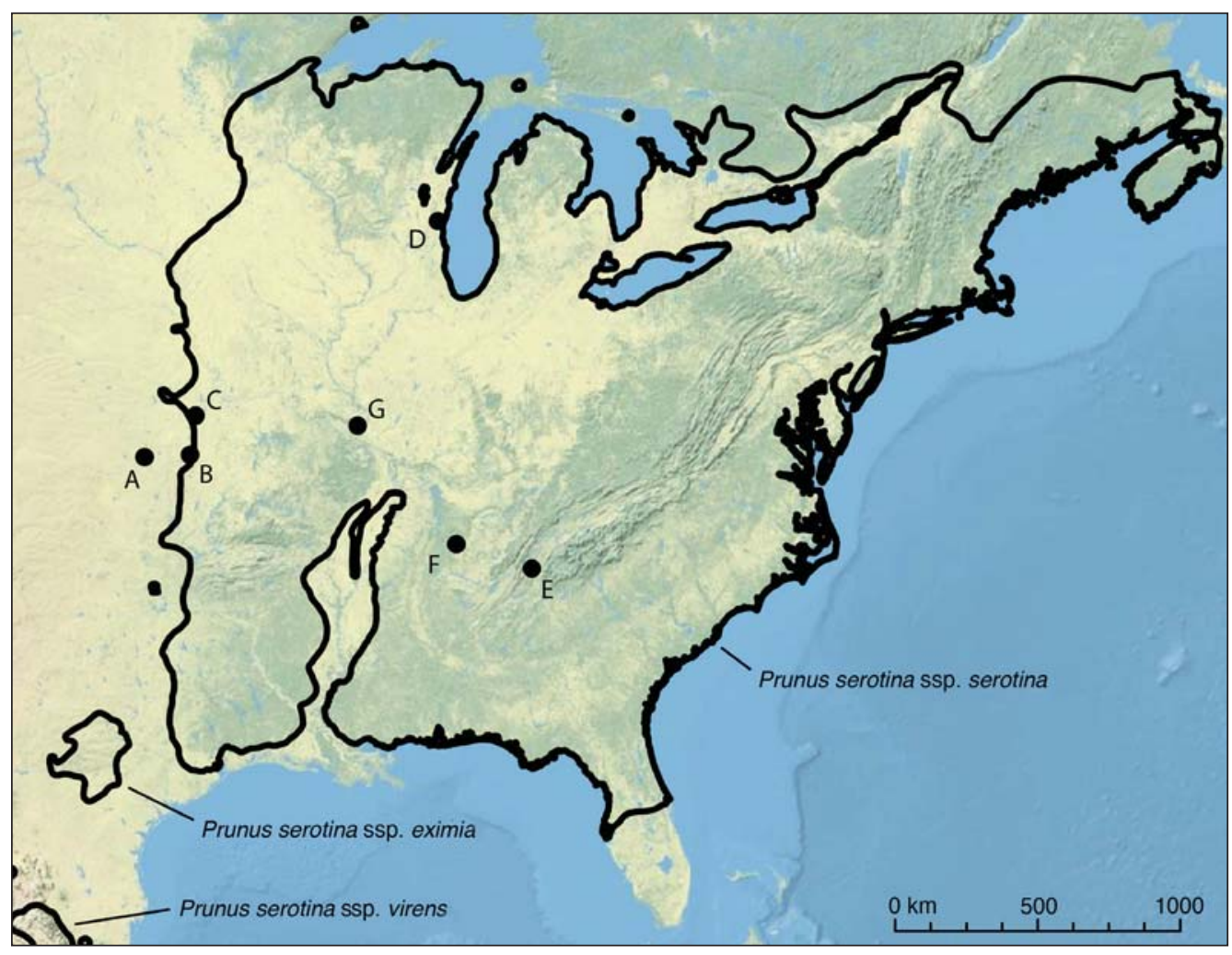

Figure 1. Generalized range (following Prasad and Iverson 2003) of Black Cherry (Prunus serotina subsp. serotina) and the locations of the seven analyzed populations. Populations are as follows: A) Chisholm Creek Park, KS; B) Cross Timbers State Park, KS; C) Osage State Fishing Lake, KS; D) University of Wisconsin-Milwaukee Field Station, WI; E) Catoosa County, GA; F) Lewis County, TN; and G) Tyson Research Center, MO. 


\section{Data analysis}

Within-population expected heterozygosity $\left(H_{\mathrm{E}}\right)$ at the four single-genome-specific loci (see below) was calculated in GenAlEx 6.0 (Peakall and Smouse 2006). Data at the 2-genome locus M4c were randomly subsampled to produce a maximum of two alleles per individual in GenoDive 2.0 (Meirmans and Van Tienderen 2004), and a sample-size-corrected measure of within-population allelic richness across all loci $(A)$ was then calculated in HP-Rare (Kalinowski 2005). We evaluated differences between mean interior vs. mean edge $H_{\mathrm{E}}$ and $A$ with Welch's $t$-tests on the R platform (R Foundation for Statistical Computing, Vienna, Austria).

\section{Results}

No more than two alleles per individual were amplified at UDP96-005, UDP98405, and UCD-CH14, consistent with the claim that these loci amplify one of the two P. serotina subsp. serotina parental genomes (Pairon and Jacquemart 2008). In addition, PceGA34 also exhibited no more than two alleles per individual, suggesting that it also targets a single genome. As previously demonstrated in Pairon and Jacquemart (2008), M4c frequently exhibited 3-4 (but not more than 4) alleles per individual. Details regarding the size and variability of each locus, along with measures of within-population variability are presented in Table 1. Although within-population $H_{\mathrm{E}}$ (averaged across loci) did not significantly differ between edge $(0.732)$ and interior $(0.748)$ populations $(t[4.03]=-0.46, P=0.6721)$, average within-population $A$ was significantly lower in edge (5.91) relative to interior (7.50) populations $(t[3.84]=-3.37, P=0.02975)$. Average within-population $A$ was lower across edge populations at all five loci (UDP96-005: edge 4.33 vs. interior 4.51;

Table 1. Size and variability of the 5 SSR loci across all populations and diversity across loci within populations. Size $=$ fragment-size range in bp, \# alleles $=$ number of alleles, $H_{\mathrm{o}}=$ observed heterozygosity, $H_{\mathrm{E}}=$ expected heterozygosity, $n=$ sample size, \# genotypes $=$ number of unique multilocus genotypes, and $A=$ allelic richness. Per-locus heterozygosity measures were not calculated for the tetraploid locus M4c, and within-population heterozygosity measures were calculated excluding this locus. Allelic richness was calculated with "diploidized" locus M4c.

\begin{tabular}{|c|c|c|c|c|c|c|c|}
\hline Locus & \multicolumn{2}{|c|}{ Size } & \multicolumn{2}{|c|}{ \# alleles } & $H_{\mathrm{o}}$ & \multicolumn{2}{|c|}{$H_{\mathrm{E}}$} \\
\hline UDP96-005 & \multicolumn{2}{|c|}{$91-11$} & \multicolumn{2}{|c|}{9} & 0.707 & \multicolumn{2}{|c|}{0.682} \\
\hline UDP98-405 & \multicolumn{2}{|c|}{$109-125$} & \multicolumn{2}{|c|}{9} & 0.521 & \multicolumn{2}{|c|}{0.552} \\
\hline UCD-CH14 & \multicolumn{2}{|c|}{$124-178$} & \multicolumn{2}{|c|}{28} & 0.871 & \multicolumn{2}{|c|}{0.869} \\
\hline PceGA34 & \multicolumn{2}{|c|}{$128-174$} & \multicolumn{2}{|c|}{21} & 0.900 & \multicolumn{2}{|c|}{0.860} \\
\hline M4c & \multicolumn{2}{|c|}{$65-95$} & \multicolumn{2}{|c|}{15} & - & \multicolumn{2}{|c|}{-} \\
\hline Population & & $n$ & \# alleles & \# genotypes & $H_{\mathrm{o}}$ & $H_{\mathrm{E}}$ & $A$ \\
\hline Chisholm Cr & & 20 & 31 & 20 & 0.725 & 0.681 & 5.38 \\
\hline Cross Timbe & , KS & 20 & 39 & 20 & 0.763 & 0.774 & 6.66 \\
\hline Osage State & e, KS & 20 & 35 & 20 & 0.750 & 0.741 & 5.69 \\
\hline UWM Field & & 20 & 58 & 20 & 0.725 & 0.799 & 8.07 \\
\hline Catoosa Cou & & 10 & 41 & 10 & 0.700 & 0.704 & 7.69 \\
\hline Lewis Count & & 20 & 48 & 20 & 0.788 & 0.729 & 6.78 \\
\hline Tyson Resea & MO & 20 & 51 & 20 & 0.800 & 0.758 & 7.46 \\
\hline
\end{tabular}


UDP98-405: 3.41 vs. 4.23; UCD-CH14: 7.46 vs. 11.40; PceGA34: 8.24 vs. 10.22; M4c: 6.11 vs. 7.15). Although this difference was only statistically significant at UCD-CH14, our limited sample size (seven populations) likely constrained our power to detect effects.

\section{Discussion}

Our finding of reduced within-population genetic diversity in range-edge populations is consistent with previous work. Eckert et al. (2008) identified 68 studies that statistically evaluated this claim, and $65 \%$ found significantly lowered withinpopulation genetic diversity towards at least one range limit. It is also not surprising that allelic richness was significantly lower in edge populations, while expected heterozygosity was not. As a measure of the number of alleles present in a population, $A$ is more sensitive to the presence/absence of rare alleles, which are most vulnerable to loss through genetic drift. Edge populations are thought to be more strongly influenced by such drift due to relatively frequent extinction/recolonization and population size fluctuations, although tests of these demographic hypotheses have received mixed results (Murphy et al. 2006, Sagarin and Gaines 2002).

While we made no formal measures of such population dynamics in these seven populations, field observations suggest that the edge populations are prone to demographic fluctuations. Both recent mortality in trees of all size classes and clear signs of drought stress in living trees (wilting and leaf scorch) were frequently observed. In addition, only one of 60 trees sampled in the edge populations was in fruit. This anecdotal evidence suggests that these populations, presumably at their adaptive limit to precipitation, are declining in response to extreme drought conditions during 2011 and 2012 in the Midwest (NDMC 2013). Long-term monitoring of fitness and demography in these and other P. serotina subsp. serotina populations at this precipitation gradient is needed to fully evaluate this possibility.

The examined edge populations exhibited reduced genetic variability relative to interior populations, but this may not be a general feature of the P. serotina subsp. serotina range boundary. Although they did not statistically compare them to interior populations, Pairon et al. (2010) included three populations from near the western range limit in Nebraska and Oklahoma in their analysis of invasive Black Cherry in Europe relative to native North American populations. Although the Oklahoma population displayed the lowest allelic richness, the Nebraska sites exhibited allelic richness measures that were higher than those of many interior populations. Indeed, we have examined a single small section of the expansive range edge of Black Cherry (Fig. 1), and populations along this boundary likely experience many selective environments. We also classified all populations as either interior or edge, but an optimal strategy for an expanded study might describe the geographic position of each population as a continuous variable such as distance to range edge (Murphy et al. 2006). Future study of P. serotina subsp. serotina, that samples densely within all portions of the range interior and along the entire range boundary (see Eckert et al. 2008) is warranted. This and other expansive 
range-edge studies of taxa with similar distributions in North American will advance our understanding of species distributions and are of particular interest due to changing environmental conditions in the region.

\section{Acknowledgments}

The authors would like to thank the following for permission to collect on their properties: the Kansas Department of Wildlife, Parks, and Tourism, Pratt, KS; The Wichita Department of Park and Recreation (Chisholm Creek Park), Wichita, KS; Tyson Research Center at Washington University, St. Louis, MO; the University of Wisconsin-Milwaukee Field Station, Saukville, WI; and the Tennessee Army National Guard Volunteer Training Site, Catoosa County, GA. Special thanks go to Gretchen Meyer and Jim Reinartz (UWM Field Station), Travis Mohrman (Tyson Research Center), and Jim Mason (Great Plains Nature Center) for facilitating fieldwork; to Paul Beck for obtaining and optimizing the reciprocating saw bead-mill; and to Cristian Beza for help preparing Figure 1. Funding for this project was provided by the Wichita State University Department of Biological Sciences and the Department of Biological and Environmental Sciences at the University of Tennessee at Chattanooga. This is contribution no. 14-303-J from the Kansas Agricultural Experiment Station.

\section{Literature Cited}

Alexander, P.J., G. Rajanikanth, C.D. Bacon, and C.D. Bailey. 2007. Recovery of plant DNA using a reciprocating saw and silica-based columns. Molecular Ecology Notes 7:5-9.

Antonovics, J. 1976. The nature of limits to natural selection. Annals of the Missouri Botanical Garden 63:224-247.

Barbour, M.G., and N.L. Christensen. 1993. Vegetation. Pp. 97-131, In Flora of North America Editorial Committee (Eds.). Flora of North America North of Mexico. Oxford University Press, New York, NY. 372 pp.

Beck, J.B., P.J. Alexander, L. Allphin, I.A. Al-Shehbaz, C. Rushworth, C.D. Bailey, and M.D. Windham. 2012. Does hybridization drive the transition to asexuality in diploid Boechera? Evolution 66:985-995.

Bridle, J.R., and T.H. Vines. 2007. Limits to evolution at range margins: When and why does adaptation fail? Trends in Ecology and Evolution 22:140-147.

Brown, J.H. 1984. On the relationship between abundance and distribution of species. American Naturalist 124:255-279.

Cipriani, G., G. Lot, W.-G. Huang, M.T. Marrazzo, E. Peterlunger, and R. Testolin. 1999. AC/GT and AG/CT microsatellite repeats in Peach [Prunus persica (L.) Batsch]: Isolation, characterization, and cross-species amplification in Prunus. Theoretical and Applied Genetics 99:65-72.

Downey, S.L., and A.F. Iezzoni. 2000. Polymorphic DNA markers in Black Cherry (Prunus serotina) are identified using sequences from Sweet Cherry, Peach, and Sour Cherry. Journal of the American Society for Horticultural Science 125:76-80.

Eckert, C.G., K.E. Samis, and S.C. Lougheed. 2008. Genetic variation across species' geographical ranges: The central-marginal hypothesis and beyond. Molecular Ecology 17:1170-1188.

Hoffmann, A.A., and M.W. Blows. 1994. Species borders: Ecological and evolutionary perspectives. Trends in Ecology and Evolution 9:223-227. 
Kalinowski, S.T. 2005. HP-RARE 1.0: a computer program for performing rarefaction on measures of allelic richness. Molecular Ecology Notes 5:187-189.

Kartesz, J.T. The Biota of North America Program (BONAP). 2013. North American plant atlas. Available online at http://www.bonap.org/MapSwitchboard.html. Accessed 1 May 2013.

Kirkpatrick, M., and N.H. Barton. 1997. Evolution of a species' range. American Naturalist $150: 1-23$.

Küchler, A.W. 1972. The oscillations of the mixed prairie in Kansas. Erdkunde 26:120-129.

Mayr, E. 1963. Animal Species and Evolution. Belknap Press of Harvard University, Cambridge, UK. 797 pp.

McVaugh, R. 1951. A revision of the North American Black Cherries (Prunus serotina Ehrh., and relatives). Brittonia 7:279-315.

Meirmans, P.G., and P.H. Van Tienderen. 2004. GENOTYPE and GENODIVE: Two programs for the analysis of genetic diversity of asexual organisms. Molecular Ecology Notes 4:792-794.

Murphy, H.T., J. VanDerWal, and J. Lovett-Doust. 2006. Distribution of abundance across the range in eastern North American trees. Global Ecology and Biogeography 15:63-71.

National Drought Mitigation Center (NDMC). 2013. US Drought Monitor. Available online at http://droughtmonitor.unl.edu/. Accessed 1 May 2013.

Pairon, M., and A. Jacquemart. 2008. Detection and characterization of genome-specific microsatellite markers in the allotetraploid Prunus serotina. Journal of the American Society for Horticultural Science 133:390-395.

Pairon, M., B. Petitpierre, M. Campbell, A. Guisan, O. Broennimann, P.V. Baret, A. Jacquemart, and G. Besnard. 2010. Multiple introductions boosted genetic diversity in the invasive range of Black Cherry (Prunus serotina; Rosaceae). Annals of Botany (London) 105:881-890.

Peakall, R., and P.E. Smouse. 2006. GENALEX 6: Genetic analysis in Excel. Population genetic software for teaching and research. Molecular Ecology Notes 6:288-295.

Prasad, A.M., and L.R. Iverson. 2003. Little's range and FIA importance-value database for 135 eastern US tree species, Northeastern Research Station, USDA Forest Service, Delaware, OH. Available online at http://www.fs.fed.us/nrs/atlas/littlefia/index.html\#. Accessed 1 May 2013.

Sagarin, R.D., and S.D. Gaines. 2002. The "abundant centre" distribution: To what extent is it a biogeographical rule? Ecology Letters 5:137-147.

Sexton, J.P., P.J. McIntyre, A.L. Angert, and K.J. Rice. 2009. Evolution and ecology of species range limits. Annuual Review of Ecology, Evolution, and Systematics 40:415-436.

Struss, D., R. Ahmad, S.M. Southwick, and M. Boritzki. 2003. Analysis of Sweet Cherry (Prunus avium L.) cultivars using SSR and AFLP markers. Journal of the American Society for Horticultural Science 128:904-909.

Vucetich, J.A., and T.A. Waite. 2003. Spatial patterns of demography and genetic processes across the species' range: Null hypotheses for landscape conservation genetics. Conservation Genetics 4:639-645.

Yamamoto, T., K. Mochida, T. Imai, Y.Z. Shi, I. Ogiwara, and T. Hayashi. 2002. Microsatellite markers in Peach [Prunus perica (L.) Batsch] derived from an enriched genomic and cDNA libraries. Molecular Ecology Notes 2:298-301. 